\title{
Identifikasi Tingkat Kesehatan Karang Berdasarkan Coral Health Chart Menggunakan Pengolahan Citra Digital Dan Metode Kuadrat Terkecil
}

\author{
Arista Mandagi ${ }^{1}$, Luther Latumakulita ${ }^{2}$, Altien Rindengan ${ }^{3}$ \\ ${ }^{1}$ Program Studi Matematika, FMIPA, UNSRAT Manado, aristamandagi@ gmail.com \\ ${ }^{2}$ Program Studi Matematika, FMIPA, UNSRAT Manado, latumakulitala@unsrat.ac.id \\ ${ }^{3}$ Program Studi Matematika, FMIPA, UNSRAT Manado, altien@unsrat.ac.id
}

\begin{abstract}
Abstrak
Terumbu karang bermanfaat bagi kelangsungan hidup makhluk bawah air. Namun saat ini terancam keberadaannya, salah satu penyebab adalah peningkatan suhu Bumi sehingga banyak terumbu karang mengalami kerusakan ditandai dengan pemutihan warna karang. Pengamatan kesehatan karang dapat dilakukan dengan tabel kesehatan karang (Coral Health Chart). Penelitian ini dimulai dengan menghitung nilai rata-rata RGB (red, green, blue) dengan pengolahan citra digital terhadap Coral Health Chart, dan menerapkan metode kuadrat terkecil untuk memperoleh perumusan dalam rangka penentuan tingkat kesehatan dari terumbu karang menggunakan bantuan komputer. Langkah selanjutnya hitung nilai rata-rata $R G B$ dari beberapa gambar karang dengan pengolahan citra digital, kemudian diterapkan pada perumusan yang telah diperoleh sebelumnya. Penelitian dilakukan pada 8 contoh gambar karang, hasilnya menunjukan tingkat kesehatan karang dan persentase tingkat kesehatan dari masing-masing karang yaitu untuk karang dengan simbol $j=95.52 \%, k=65.02 \%, l=80.42 \%, m=81.11 \%, n=84.69 \%, o=52.87 \%, p=79.41 \%$ dan karang $q=69.78 \%$.
\end{abstract}

Kata kunci : Tabel Kesehatan Karang, Pengolahan Citra Digital, Kesehatan Karang, Metode Kuadrat Terkecil

\section{Identification Of Coral Health Level Based On Coral Health Chart Using Digital Image Processing And Least Square Method}

\begin{abstract}
Coral reefs are beneficial for the survival of underwater creatures. However coral reefs currently endangered, one of caused is the increase of earth temperature so many coral reefs were damaged and marked with color bleaching on coral. Observation on coral health can be done with Coral Health Chart. This research begins from calculated the average RGB (red, green, blue) value with digital image processing for the Coral Health Chart, and applying the least squares method to obtain a formula in order to determine the health level of coral reefs using computer. Next step is calculated the average RGB from some coral image by digital image processing and then applied to a formula which has been previously obtained. The research was conducted at 8 coral example pictures, the results show coral health rate and percentage rate of coral health, where for coral with symbol $j=95.52 \%, k=65.02 \%, l=80.42 \%, m=81.11 \%, n=84.69 \%$, $o=52.87 \%, p=79.41 \%$ and $q=69.78 \%$.
\end{abstract}

Keywords : Coral Health Chart, Digital Image Processing, Coral Health, Least Square Method

\section{Pendahuluan}

Lautan merupakan daerah yang sangat luas sehingga menjadikannya menarik untuk diamati. Selain itu lautan menjadi sumber keuntungan ekonomi yang besar bagi suatu Negara karena perikanan dan pariwisata, serta ekosistem terumbu karang. Terumbu karang saat ini terancam keberadaannya, hal tersebut disebabkan karena kondsi peningkatan suhu perairan Bumi, sehingga terjadi kerusakan pada karang yang ditandai dengan pemutihan warna karang. Pemutihan karang ialah pemudaran warna karang akibat punahnya alga simbiotik sebagai pemberi energi dan warna pada jaringan karang [1]. Belum banyak yang dimengerti dari mekanisme pemutihan karang, akan tetapi kenaikan suhu mengganggu kemampuan alga untuk berfotosintesis dan dapat memicu produksi kimiawi berbahaya yang merusak sel-sel mereka [2]. 
Penglihatan berperan penting dalam persepsi manusia, hal ini juga berlaku terhadap sebuah citra atau gambar. Dalam hal ini karang yang tidak sehat dapat diamati pada pola perubahan warnanya, semakin memutih berarti karang berada dalam kondisi tidak sehat. Pada tahun 2006 [3] meneliti tentang Monitoring Coral Bleaching Using a Colour Reference Card. Pada penelitian tersebut gambar dari beberapa karang dianalisa pada Adobe Photoshop V6 menggunakan fungsi histogram untuk menentukan hue, saturation dan brightness. Kemudian diolah pola perubahan warna pemutihan karang sehingga menetapkan keempat kelas warna dan menciptakan suatu Tabel Kesehatan Karang (Coral Health Chart) untuk memantau kesehatan karang. Tabel Kesehatan Karang digunakan di lapangan dengan cara membandingkan warna karang dengan warna pada tabel, lalu mencatat kode yang sesuai. Dalam penelitian ini menggunakan Tabel Kesehatan Karang (Coral Health Chart) dan memanfaatkan pengolahan citra digital yang akan memberikan informasi berupa nilai-nilai dari segi warna $R G B$ (red, green, blue) serta menggunakan metode kuadrat terkecil untuk penentuan perumusan. Dari perumusan tersebut, dapat dilakukan perhitungan terhadap tingkat kesehatan dari terumbu karang. Penelitian ini juga memanfaatkan bantuan komputer.

\section{Coral dan Coral Health Chart}

Terumbu karang (Coral) memiliki peranan yang penting bagi keanekaragaman organisme laut. Pada karang yang sehat, alga (dinoflagelata simbiotik) hidup di dalam jaringan karang. Alga memberikan energi pada karang berupa gula dan asam amino, dan memberi karakter warna pada karang. Kondisi lingkungan yang tidak baik, menyebabkan alga ini terlepas dari jaringan karang, sehingga warna karang berubah menjadi putih atau dikenal dengan pemutihan karang [1]. Penyebab utama pemutihan karang secara besar-besaran dalam kurun waktu beberapa dekade terakhir ini berhubungan dengan peningkatan suhu permukaan laut [4]. Suhu rata-rata yang terus menerus naik karena perubahan iklim dunia membuat karang hampir dapat dipastikan menjadi subjek pemutihan yang lebih sering dan ekstrim [5]. Terjadinya pemutihan masal tahun 1998 merupakan pemutihan yang paling parah dalam sejarah, karena seperenam dari koloni karang mati setiap tahun [1].

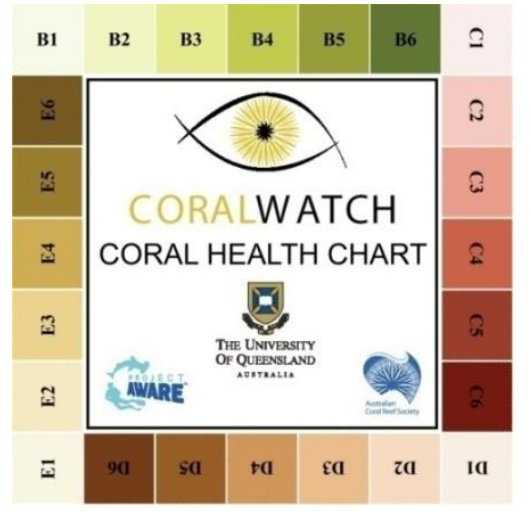

Gambar 1. Coral Health Chart

CoralWatch merupakan organisasi yang diawali dari sebuah proyek penelitian di University of Queensland, Brisbane, Australia. CoralWatch menggunakan Coral Health Chart atau Tabel Kesehatan Karang, suatu metode sederhana yang tidak merusak untuk memantau pemutihan dan kesehatan karang. Dalam tabel tersebut terdapat empat klasifikasi warna, masing-masing mewakili warna-warna dari terumbu karang yaitu warna hijau, merah, coklat serta kecoklatan [1].

\section{Pengolahan Citra Digital}

Pengolahan citra digital merupakan bidang yang berkembang pesat dengan perkembangan aplikasi dalam sains dan teknik. Istilah pengolahan citra digital umumnya mengacu pada pengolahan gambar dua dimensi dengan komputer digital. Pengolahan citra digital memiliki peranan yang luas dalam aplikasi seperti penginderaan jarak jauh melalui satelit dan pesawat ruang angkasa, transmisi gambar dan penyimpanan untuk aplikasi bisnis, pengolahan medis, radar, sonar, 
pengolahan citra akustik, robotika, dan sebagainya [6]. Image digital adalah fungsi $f(x, y)$ dengan ukuran baris $M$ dan $N$ kolom, dimana $x$ dan $y$ adalah koordinat spasial dan $f$ pada titik koordinat $(x, y)$ disebut intensitas atau tingkat keabuan dari citra pada titik tersebut.

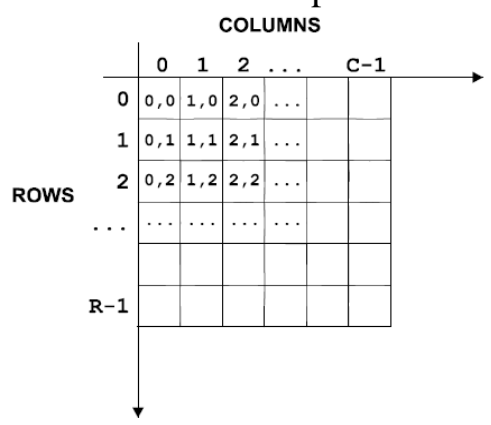

Gambar 2. Koordinat Gambar Digital

Dalam notasi matriks, ditulis:

$$
f(x, y) \approx\left[\begin{array}{cccc}
f(0,0) & f(0,1) & \ldots & f(0, M-1) \\
f(1,0) & f(1,1) & \ldots & f(1, M-1) \\
\vdots & : & : & : \\
f(N-1,0) & f(N-1,1) & \ldots & f(N-1, M-1)
\end{array}\right]
$$

Sebuah gambar digital dapat dianggap sebagai array besar dari titik-titik diskrit. Titik-titik ini disebut elemen gambar atau pixel. Dalam true color, setiap pixel memiliki warna tertentu, warna yang digambarkan oleh jumlah merah, hijau dan biru di dalamnya [7]. Setiap warna dihasilkan dengan penggabungan yang tepat ketiga warna primer atau $R G B$ [8].

Untuk $R G B$ atau merah, hijau, biru memiliki jangkauan antara 0-255, ini memberikan total $255^{3}=16.777 .261$ warna yang mungkin berbeda di dalam gambar [7]. Model warna $R G B$ berdasarkan pada warna yang direspon mata manusia yang peka terhadap panjang gelombang sekitar $400 \mathrm{~nm}$ (biru) sampai $700 \mathrm{~nm}$ (merah) [9]. Sembarang warna dapat dihasilkan dari campuran warna-warna primer $R, G, B$ dengan persentase tertentu dimana warna $(W)$ :

$$
W=R+G+B
$$

\section{Metode Kuadrat Terkecil}

Dalam bidang sains dan teknik seringkali muncul kasus dalam percobaan yang menghasilkan himpunan dari titik-titik data $\left(x_{i}, y_{i}\right), \ldots,\left(x_{N}, y_{N}\right)$ dimana absis $\left\{x_{i}\right\}_{i=1}^{N}$ tertentu. Salah satu tujuan dari metode numerik adalah menentukan formula $y=f(x)$ yang menghubungkan semua variabel [10]. Pada kasus ini digunakan fungsi linear dari bentuk:

$$
y=f(x)=a x+b
$$

Seringkali ada kesalahan percobaan dalam pengukuran, sehingga nilai sebenarnya dari $f\left(x_{i}\right)$ memenuhi:

$$
f\left(x_{i}\right)=y_{i}+e_{i}
$$

dimana $e_{i}$ adalah kesalahan atau error dalam pengukuran.

Dalam menemukan perkiraan linear terbaik dari bentuk (2) perlu dibahas mengenai error dimana

$$
e_{i}=f\left(x_{i}\right)-y_{i}
$$

Untuk mengukur seberapa jauh garis $y=f(x)$ berada pada data digunakan root-mean-square error

$$
E(f)=\left(\frac{1}{N} \sum_{i=1}^{N}\left(f\left(x_{i}\right)-y_{i}\right)^{2}\right)^{1 / 2}
$$


Teorema 1 (Least-squares Line) squares

Jika $\left\{\left(x_{i}, y_{i}\right)\right\}_{i=1}^{N}$ adalah titik-titik $N$, dimana absis $\left\{x_{i}\right\}_{i=1}^{N}$ tertentu. Koefisien dari garis least-

$$
y=a x+b
$$

merupakan solusi dari sistem linear yang dikenal sebagai persamaan normal atau normal equations:

$$
\begin{array}{r}
\left(\sum_{i=1}^{N} x_{i}^{2}\right) a+\left(\sum_{i=1}^{N} x_{i}\right) b=\sum_{i=1}^{N} x_{i} y_{i} \\
\left(\sum_{i=1}^{N} x_{i}\right) a+N b=\sum_{i=1}^{N} y_{i}
\end{array}
$$

Dengan,

$$
\begin{array}{r}
a=\frac{N \sum_{i=1}^{N} x_{i} y_{i}-\sum_{i=1}^{N} x_{i} \sum_{i=1}^{N} y_{i}}{N \sum_{i=1}^{N} x_{i}^{2}-\left(\sum_{i=1}^{N} x_{i}\right)^{2}} \\
b=\frac{\sum_{i=1}^{N} y_{i} \sum_{i=1}^{N} x_{i}^{2}-\sum_{i=1}^{N} x_{i} \sum_{i=1}^{N} x_{i} y_{i}}{N \sum_{i=1}^{N} x_{i}^{2}-\left(\sum_{i=1}^{N} x_{i}\right)^{2}}
\end{array}
$$

dimana,

$a=$ kemiringan atau gradient.

$b=$ intersep atau perpotongan dengan sumbu tegak.

\section{Pengujian Hipotesis}

Untuk menguji hipotesis apakah intersep bernilai tertentu (misalnya $\mathrm{k}$ ) dapat diuji dengan menggunakan statistik uji-t [11]. Dimana hipotesisnya dapat dituliskan sebagai berikut:

$$
\begin{aligned}
& H_{0}: b=k \\
& H_{1}: b \neq k
\end{aligned}
$$

Dengan statistik uji t:

$$
t_{\text {hitung }}=\frac{b-k}{\sqrt{\frac{\sum_{i=1}^{n} e_{i}^{2}}{(n-2)}\left(1 / n+\frac{\bar{x}^{2}}{\sum_{i=1}^{n}\left(x_{i}-\bar{x}\right)^{2}}\right)}}
$$

Nilai tabelnya adalah tabel $t$ dengan derajat bebas $(n-2)$. Jika nilai $t_{\text {hitung }}$ lebih besar dari nilai $t_{\alpha / 2},(n-2)$ maka hipotesis nol ditolak yang berarti bahwa nilai $b \neq k$.

Sedangkan untuk melihat apakah peubah $x$ berpengaruh terhadap peubah $y$ juga dapat diuji dengan menggunakan uji-t. Hipotesisnya dapat dituliskan sebagai berikut:

$$
\begin{aligned}
& H_{0}: a=k \\
& H_{1}: a \neq k
\end{aligned}
$$

Dengan statistik uji-t:

$$
t_{\text {hitung }}=\frac{a-k}{\sqrt{\frac{\sum_{i=1}^{n} e_{i}^{2}}{(n-2)}\left(1 / \sum_{i=1}^{n}\left(x_{i}-\bar{x}\right)^{2}\right)}}
$$

Nilai tabelnya adalah tabel $t$ dengan derajat bebas $(n-2)$. Jika nilai $t_{\text {hitung }}$ lebih besar dari nilai $t_{\alpha / 2},(n-2)$, maka hipotesis nol ditolak. Jika hipotesis nol ditolak itu berarti bahwa ada pengaruh peubah $x$ terhadap $y$ sebesar $k$ [11]. 


\section{Metode Penelitian}

Langkah-langkah:

1) Mengambil gambar digital Tabel Kesehatan Karang (Coral Health Chart) dari CoralWatch.

2) Menerapkan pengolahan citra digital pada Tabel Kesehatan Karang (Coral Health Chart) untuk mencari nilai rata-rata $R G B$ dari keempat kelas warna.

3) Menentukan perumusan Tabel Kesehatan Karang (Coral Health Chart) dengan metode kuadrat terkecil berdasarkan nilai rata-rata $R G B$ dari keempat kelas warna yang telah diperoleh sebelumnya.

4) Ambil beberapa contoh gambar terumbu karang.

5) Tentukan klasifikasi kelas warna karang.

6) Terapkan pengolahan citra digital pada gambar terumbu karang untuk mencari nilai rata-rata $R G B$.

7) Menentukan dan menyimpulakan tingkat kesehatan karang dengan perumusan dari Tabel Kesehatan Karang (Coral Health Chart).

Seluruh sistem diagram alir penelitian dapat dilihat pada Gambar 3.

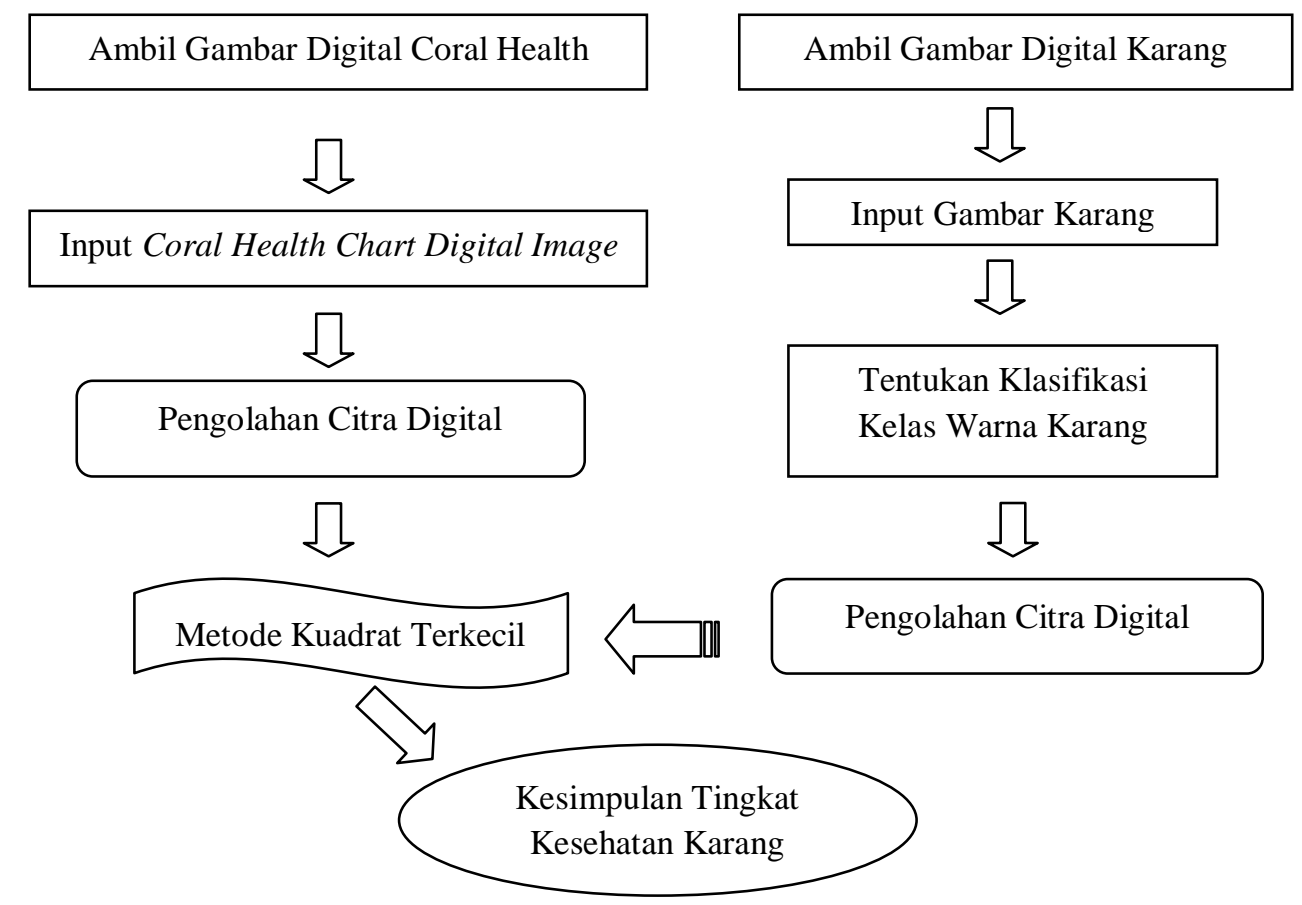

Gambar 3. Diagram Alir Penelitian

\section{Hasil dan Pembahasan}

\subsection{Penerapan Pengolahan Citra Digital dan Metode Kuadrat Terkecil pada Tabel Kesehatan Karang (Coral Health Chart)}

Pada penelitian ini diamati Tabel Kesehatan Karang (Coral Health Chart) dari segi warna dengan menggunakan pengolahan citra digital. Dalam kasus ini warna diteliti berdasarkan 3 warna primer utama yaitu $R G B$ (red, green, blue). 


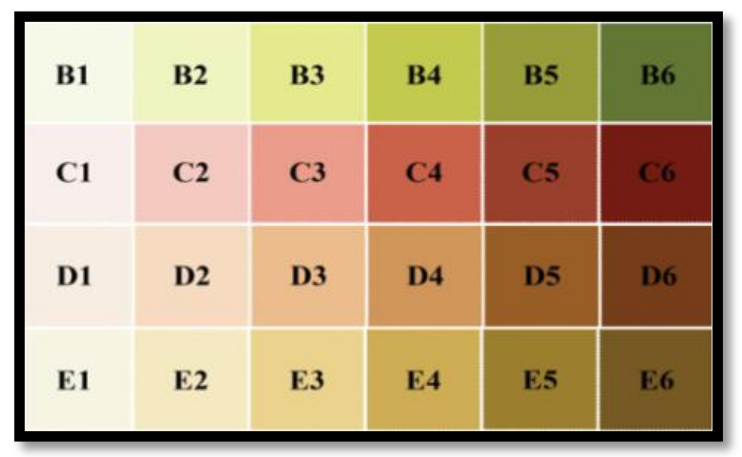

Gambar 4. Empat Kelas Warna (Coral Health Chart)

Langkah awal yang dilakukan, diambil citra digital dari Tabel Kesehatan Karang (Coral Health Chart) yang diteliti dalam empat bagian pengelompokan warna atau kita sebut kelas warna. Dari keempat kelas warna dibagi kelas $B, C, D$ dan $E$ masing-masing $B 1, B 2, B 3, B 4, B 5, B 6$ dan seterusnya. Range warna 1-6 merupakan pengukuran dari proses perubahan warna pada karang atau tingkat kesehatan karang, semakin karang memutih berarti karang berada dalam kondisi yang tidak sehat. Kemudian masing-masing warna dihitung nilai rata-rata $R G B$ dengan bantuan komputer berdasarkan persamaan (1), dimana nilai rata-rata warna $R G B$ merupakan variabel $x$ dan range warna 1-6 merupakan variabel $y$, seperti disajikan pada Tabel 1.

Tabel 1. Rata-rata $R G B$ masing-masing kelas warna

\begin{tabular}{|r|r|r|r|r|}
\hline$Y$ & nilai warna $B(x)$ & nilai warna $C(x)$ & nilai warna $D(x)$ & nilai warna $E(x)$ \\
\hline 1 & 236.7455 & 237.0596 & 231.9768 & 234.2275 \\
\hline 2 & 221.5258 & 209.8393 & 215.0153 & 220.1722 \\
\hline 3 & 199.096 & 176.7289 & 185.9306 & 195.1196 \\
\hline 4 & 158.5537 & 127.0960 & 149.7425 & 155.4355 \\
\hline 5 & 124.2744 & 92.4093 & 99.0339 & 112.9233 \\
\hline 6 & 95.0492 & 61.5242 & 74.2287 & 86.9530 \\
\hline
\end{tabular}

Berdasarkan hasil tersebut dengan memanfaatkan bantuan komputer, nilai-nilai dari nilai rata-rata warna $R G B$ yang telah didapatkan diolah dengan metode kuadrat terkecil, sedemikian sehingga menghasilkan perumusan yang nantinya akan membantu dalam penentuan kesehatan karang. Plot dari masing-masing kelas warna berdasarkan nilai-nilai pada Tabel 1, disajikan pada Gambar 5 dan Gambar 6.

Error dari masing-masing kelas warna dengan menngunakan persamaan (5) adalah kelas $B=2.62 \%$, kelas $C=0.97 \%$, kelas $D=3.26 \%$ dan kelas $E=3.2 \%$.

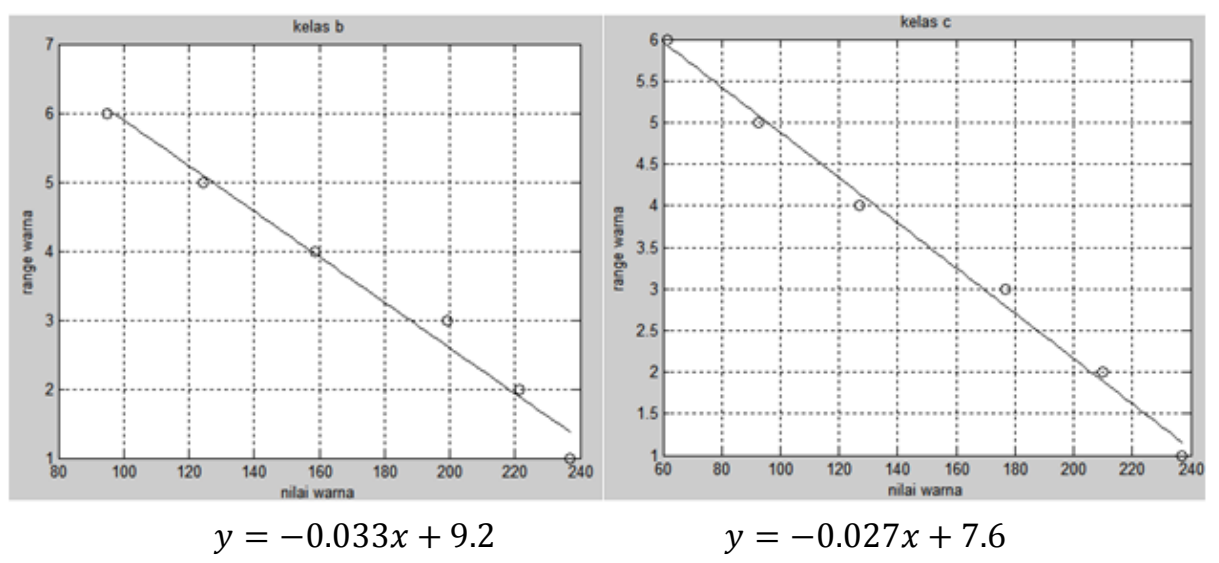

Gambar 5. Plot dan Perumusan Kelas Warna $B$ dan $C$ 


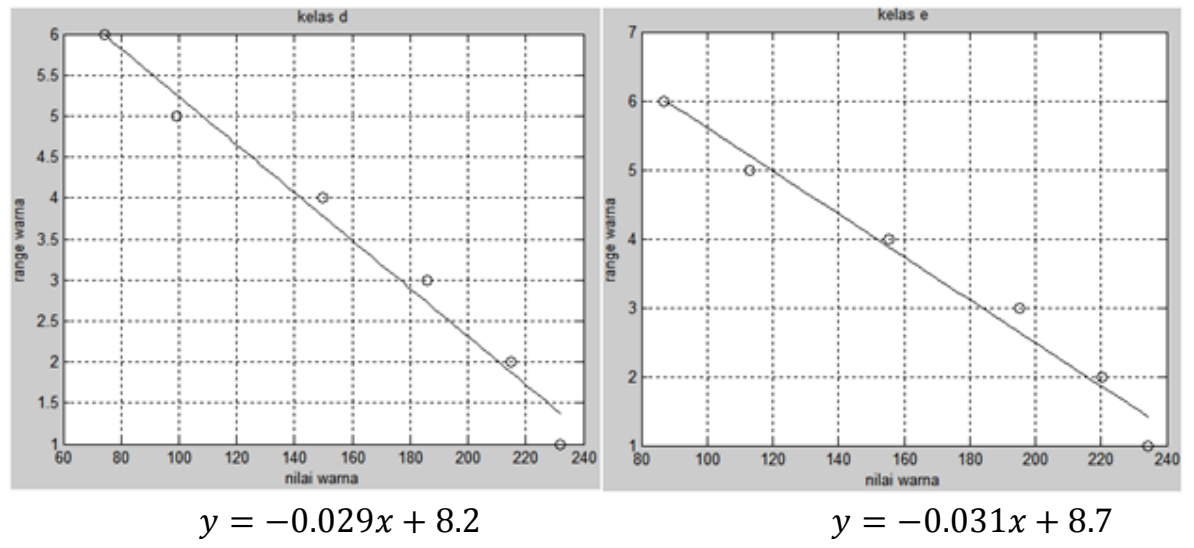

Gambar 6. Plot dan Perumusan Kelas Warna $D$ dan $E$

\subsection{Pengujian hipotesis}

Untuk menguji hipotesis apakah intersep bernilai tertentu, dapat diuji dengan menggunakan statistik uji-t, hipotesisnya dapat dituliskan sebagai berikut:

$$
\begin{aligned}
& H_{0}: b=0 \\
& H_{1}: b \neq 0
\end{aligned}
$$

Nilai t-tabelnya adalah $t_{0.05 / 2,(6-2)}=t_{0.025,(4)}=2.776$.

Untuk kelas $B$ :

$$
t_{\text {hitung }}=\frac{9.2-0}{\sqrt{\left(\frac{0.314167}{(6-2)}\right)\left(1 / 6+\frac{(172.541)^{2}}{15757.269}\right)}}=\frac{9.2}{0.402}=22.89
$$

$t_{\text {hitung }}>t_{\text {tabel }}$ atau $22.89>2.776$

Untuk kelas $C$ :

$$
t_{\text {hitung }}=\frac{7.6-0}{\sqrt{\left(\frac{0.116657}{(6-2)}\right)\left(1 / 6+\frac{(150.7762)^{2}}{23540.18}\right)}}=\frac{7.6}{0.182}=41.82
$$

$t_{\text {hitung }}>t_{\text {tabel }}$ atau $41.82>2.776$

Untuk kelas $D$ :

$$
t_{\text {hitung }}=\frac{8.2-0}{\sqrt{\left(\frac{0.391689}{(6-2)}\right)\left(1 / 6+\frac{(159.321)^{2}}{20055.77}\right)}}=\frac{8.2}{0.3745}=21.895
$$

$t_{\text {hitung }}>t_{\text {tabel }}$ atau $21.895>2.776$

Untuk kelas $E$ :

$$
t_{\text {hitung }}=\frac{8.7-0}{\sqrt{\left(\frac{0.383795}{(6-2)}\right)\left(1 / 6+\frac{(167.4719)^{2}}{17601.75}\right)}}=\frac{8.7}{0.411}=21.17
$$

$t_{\text {hitung }}>t_{\text {tabel }}$ atau $21.17>2.776$

Dari keempat kelas warna, karena $t_{\text {hitung }}>t_{\text {tabel }}$, maka hipotesis nol ditolak yang berarti bahwa nilai $b \neq 0$. Berarti bahwa garis regresi penduga $y$ tidak melalui titik acuan $(x, y)=(0,0)$. Sedangkan untuk melihat apakah peubah $x$ berpengaruh terhadap peubah $y$, hipotesisnya dapat dituliskan sebagai berikut:

$H_{0}: a=0$ (nilai warna pada gambar tidak mempengaruhi tingkat kesehatan karang)

Untuk kelas $B$ :

$H_{1}: a \neq 0$ (nilai warna pada gambar mempengaruhi tingkat kesehatan karang)

$$
\begin{gathered}
t_{\text {hitung }}=\frac{-0.033-0}{\sqrt{0.0785(1 / 15757.269)}}=\frac{-0.033}{0.00223}=-14.79 \\
\left|t_{\text {hitung }}\right|>t_{\text {tabel }} \text { atau }|-14.79|>2.776
\end{gathered}
$$


Untuk kelas $C$ :

$$
\begin{gathered}
t_{\text {hitung }}=\frac{-0.027-0}{\sqrt{0.029(1 / 23540.184)}}=\frac{-0.027}{0.00111}=-24.32 \\
\left|t_{\text {hitung }}\right|>t_{\text {tabel }} \text { atau }|-24.32|>2.776
\end{gathered}
$$

Untuk kelas $D$ :

$$
\begin{gathered}
t_{\text {hitung }}=\frac{-0.029-0}{\sqrt{0.0979(1 / 20055.77)}}=\frac{-0.029}{0.00221}=-13.12 \\
\left|t_{\text {hitung }}\right|>t_{\text {tabel }} \text { atau }|-13.12|>2.776
\end{gathered}
$$

Untuk kelas $E$ :

$$
\begin{gathered}
t_{\text {hitung }}=\frac{-0.031-0}{\sqrt{0.096(1 / 17601.75)}}=\frac{-0.031}{0.0023354}=-13.27 \\
\left|t_{\text {hitung }}\right|>t_{\text {tabel }} \text { atau }|-13.27|>2.776
\end{gathered}
$$

Dari keempat kelas warna, karena $\left|t_{\text {hitung }}\right|>t_{\text {tabel }}$ maka tolak $H_{0}$, jadi kesimpulannya nilai warna pada gambar mempengaruhi tingkat kesehatan karang.

\subsection{Penentuan Kesehatan Terumbu Karang}

Pada penelitian ini diambil beberapa contoh gambar karang dari pantai Surabaya, Desa Wineru Kecamatan Likupang Timur, Kabupaten Minahasa Utara, Provinsi Sulawesi Utara dengan menggunakan kamera resolusi 8 Megapixel. Setelah gambar digital dari karang didapatkan, tentukan klasifikasi kelas warna dari karang tersebut. Kemudian memanfaatkan pengolahan citra digital pada gambar karang tersebut dengan menghitung nilai rata-rata $R G B$, serta menentukan kesehatan karang dari perumusan yang telah didapatkan sebelumnya melalui metode kuadrat terkecil. Delapan contoh gambar karang yang diteliti dapat dilihat pada Gambar 7.

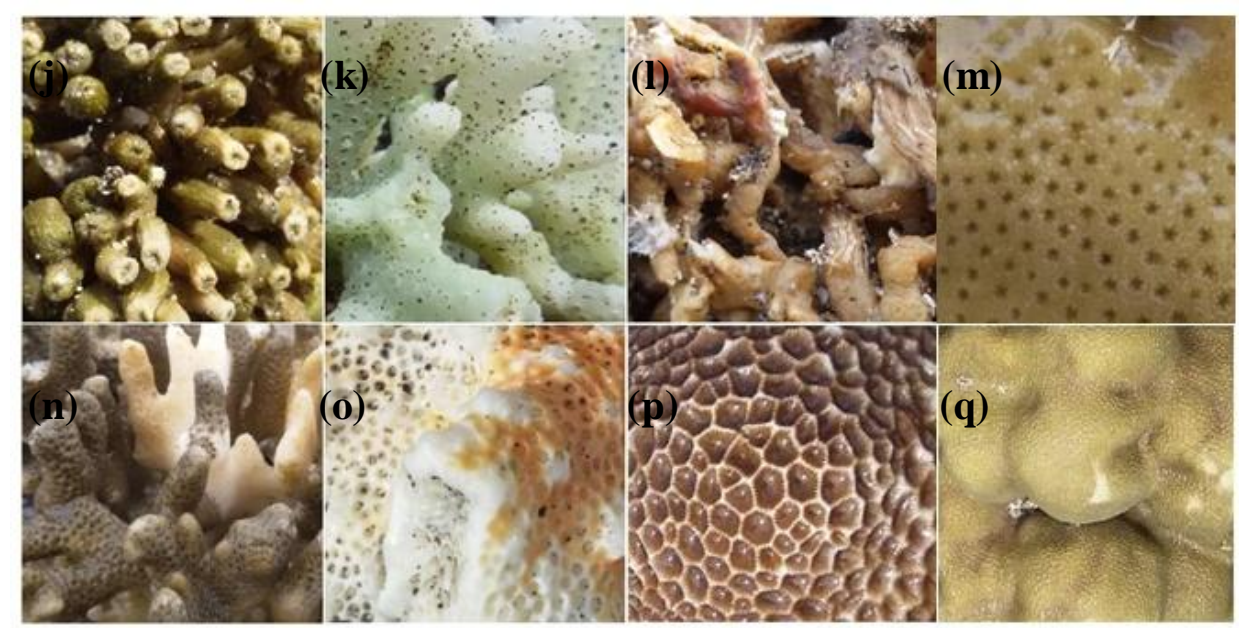

Gambar 7. Beberapa Contoh Terumbu Karang (Xenia sp, Acropora sp, Porites sp)

Setelah nilai rata-rata $R G B$ dari masing-masing gambar terumbu karang didapatkan dan kelas warna dipastikan kemudian gunakan perumusan yang telah didapatkan sebelumnya yaitu perumusan dari 4 kelas warna menggunakan metode kuadrat terkecil, untuk mencari nilai $y$ dan mengetahui tingkat kesehatan karang. Hasil dari perhitungan nilai rata-rata $R G B$ masing-masing terumbu karang diatas serta persentase dari tingkat kesehatan karang disajikan pada Tabel 2.

Dari hasil yang didapatkan menunjukkan beberapa terumbu karang berada pada tingkat kesehatan yang berbeda, ada karang yang masih dalam kondisi sehat namun ada juga karang yang mengalami pemutihan, tidak menutup kemungkinan pada beberapa karang yang sehat akan mengalami pemutihan jika kelangsungan hidup makhluk bawah air di lautan terutama keberadaan terumbu karang tidak dijaga atau dilestarikan. 
Tabel 2. Penentuan Kesehatan Karang

\begin{tabular}{|c|r|c|c|c|}
\hline Kode & $\begin{array}{c}\text { Nilai Rata-Rata } \\
\text { Gambar }(x)\end{array}$ & $\begin{array}{c}\text { Kelas } \\
\text { Warna }\end{array}$ & $\begin{array}{c}\text { Nilai } y \\
\text { (tingkat kesehatan) }\end{array}$ & $\begin{array}{c}\text { Persentase Tingkat } \\
\text { Kesehatan Karang }\end{array}$ \\
\hline $\boldsymbol{j}$ & 95.7518 & $E$ & 5.7317 & $95.52 \%$ \\
\hline $\boldsymbol{k}$ & 160.5543 & $B$ & 3.9017 & $65.02 \%$ \\
\hline $\boldsymbol{l}$ & 124.9917 & $E$ & 4.8253 & $80.42 \%$ \\
\hline $\boldsymbol{m}$ & 123.6317 & $E$ & 4.8674 & $81.11 \%$ \\
\hline $\boldsymbol{n}$ & 107.5225 & $D$ & 5.0818 & $84.69 \%$ \\
\hline $\boldsymbol{o}$ & 173.3538 & $D$ & 3.1727 & $52.87 \%$ \\
\hline $\boldsymbol{p}$ & 118.4621 & $D$ & 4.7646 & $79.41 \%$ \\
\hline $\boldsymbol{q}$ & 145.5756 & $E$ & 4.1872 & $69.78 \%$ \\
\hline
\end{tabular}

\section{Kesimpulan}

- Pemanfaatan pengolahan citra digital dan metode kuadrat terkecil pada Coral Health Chart dapat menghasilkan empat perumusan berdasarkan empat klasifikasi kelas warna, sehingga tingkat kesehatan karang dapat diidentifikasi.

- Ada delapan contoh gambar karang dari pantai Surabaya, Desa Wineru, Kecamatan Likupang Timur, Kabupaten Minahasa Utara, Provinsi Sulawesi Utara yang diteliti, dan dari kedelapan gambar karang tersebut persentase tingkat kesehatan dari masing-masing karang adalah $j=95.52 \%, k=65.02 \%, \quad l=80.42 \%, \quad m=81.11 \%, \quad n=84.69 \%, \quad o=52.87 \%$, $p=79.41 \%, q=69.78 \%$.

- Penelitian ini merupakan metode awal dan penentuan klasifikasi kelas warna dari terumbu karang masih dilakukan secara manual untuk itu pengembangan lebih lanjut dengan metode lain sangat diharapkan. Perlu dikembangkan lagi untuk pengambilan gambar dengan resolusi berbeda, mungkin dapat diatasi dengan metode-metode lainnya.

\section{Daftar Pustaka}

[1] CoralWatch. 2014. Online website and database of bleaching observations. http://www.coralwatch.org/web/guest/monitoring-materials [29 Desember 2014].

[2] Jones, R., O.H. Guldberg, A.W.L. Larkum, and U. Schreiber. 1998. Temperature Induced bleaching of corals begins with impairment of dark metabolism in zooxanthellae. Plant Cell and Environment 21(12):1219-1230.

[3] Siebeck, U.E., N.J. Marshall, A. Kluter, and O.H. Guldberg. 2006. Monitoring Coral Bleaching using Colour Reference Card. Coral Reefs 25:453-460.

[4] Guldberg, O.H. 1999. Climate change, coral bleaching and the future of the world's coral reefs. Marine and Freshwater Research 50(8): 839-866.

[5] Westmacott, S., K. Teleki, S. Wells, and J. West. 2000. Pengelolaan Terumbu Karang Yang Telah Memutih Dan Rusak Kritis. Terjemahan Jan Henning Steffen. The Nature Conservation Bureau Ltd Newbury. Inggris.

[6] Jain, A.K. 1989. Fundamental of Digital Image Processing. Prentice-Hall Internasional, Inc. Singapore.

[7] McAndrew, A. 2004. An introduction to Digital Image Processing with MATLAB. Victoria University of Technology. Australia.

[8] Young, T. 1992. On the Theory of Light and Colors. Philosophical Transactions of the Royal Society of London.18(02):20-71.

[9] Presetyo, E. 2011. Pengolahan Citra Digital dan Aplikasinya Menggunakan MATLAB. Penerbit Andi. Yogyakarta.

[10] Mathews, J., and K. Fink. 1999. Numerical Methods using MATLAB Third edition. Prentice Hall Upper Saddle River. USA.

[11] Hatidja, D. 2006. Metode Statistika II. F-MIPA Universitas Sam Ratulangi. Manado. 